\title{
Job Resourcefulness, Customer Orientation and Employees Outcomes: A Study of Hotel Employees in
} Pakistan

\author{
Afsheen Fatima ${ }^{1 *}$, Sarah Salah Uddin², Saba Mehmood ${ }^{3}$, Ashfeen Bibi ${ }^{4}$ \\ ${ }^{1}$ SZABIST Islamabad, Pakistan \& University Institute of Management Sciences, Pakistan \\ ${ }^{2}$ Virtual University of Pakistan \\ ${ }^{3}$ Punjab Group of Colleges and UCP Gujar Khan Campus, Pakistan \\ ${ }^{4}$ IGNITE (National ICT R\&D Fund), Pakistan \\ afsheen.uaar@gmail.com*, sarahsdin@gmail.com, sabxskages27@gmail.com, ashfeen.munir@gmail.com
}

\begin{abstract}
Increased competition and a rapidly changing environment present a huge challenge to organizations in implementing effective human capital and development strategies to boost their efficiency and overall performance. An organization's human resource is definitively its most significant asset. The provisions of important job resources help workforce perform their job in an efficient way. These resources are very important for employee satisfaction and performance of the organization. This study was carried out to examine the impact of job resourcefulness (JR) on two employee outcomes i.e., job engagement and career satisfaction directly as well as indirectly through customer orientation. A convenient sample of 257 employees was taken from hospitality industry within twin cities of Pakistan (Rawalpindi and Islamabad). Questionnaires were used to collect data using a five point Likert type scale. Job resourcefulness was operationalized using four items from Harris et al. (2006) whereas customer orientation was measured using four items from Licata et al. (2003). Five items were selected from career satisfaction scale developed by Greenhaus et al. (1990). Finally, nine items scale of job engagement developed by (Schaufeli, Bakker et al. 2006) was also used. The results exhibit that all the variables are positively and significantly related. Moreover, the findings are indicative of customer orientation's role as a mediator between job resourcefulness and employee outcomes. Recommendations for future research and research implications are also discussed at the end of the paper.
\end{abstract}

Keywords: Job resourcefulness, Customer orientation, Employee outcomes, Job engagement, Career satisfaction, Hospitality industry, Pakistan

\section{Introduction}

It is generally acknowledged that customer orientation (CO) is an essential tool to ensure the existence and development of organizations(Hurley and Hult 1998).Customer oriented employees direct their endeavors to better serve their customers (Brown, Mowen et al. 2002)for instance, attentively recognizing customer needs, creating the impetus on management to effectively meet those needs and then adapting and adjusting communication to match all customers' requirements. Research shows that worker CO contributes towards enhancing consumer loyalty(Huang and Chang 2008); customer trust and responsibility (Huang and Chang 2008), and employee performance(Babakus, Yavas et al. 2009);(Boles, Babin et al. 2001).(Saxe and Weitz 1982)characterized CO at the individual level as the extent to which customer support officer/employee engage and interact with customers to satisfy customer's requirements and contribute to their fulfillment. This concept was formally introduced in the early 1990s and led to the development of the branch of marketing called "relationship marketing". The basic premise of this concept lies on building a long term relationship with the client that is beneficial for both of them i.e., customer as well as organization.

Job resourcefulness is essential to develop and utilize the concepts of relationship marketing, more specifically customer orientation. Job resourcefulness can be developed through the realization of a few basic elements with respect to relationship marketing. Firstly, organizations through their systems and managers give employees the opportunity to develop the capacity to fulfill customer needs. Secondly, organizations must realize that in the absence of empowerment employees will feel restricted and cannot creatively fulfill requirements. Thirdly, customers should be integrated into the planning process. Customer input is significant; the customer is the entity who will be utilizing the product. In the event, that the client is not satisfied right from the start, the company may lose him which effectively means a loss in revenue. This entire system of thought needs to be built into the organizational system. The word system leads us to conclude that effective relationship marketing should emphasize teamwork. Two important outcomes of job 
resourcefulness and customer orientation are included in this study i.e., job engagement and career satisfaction. Job engagement is defined as a combination of vigor, absorption and dedication (Schaufeli, Salanova et al. 2002). Career satisfaction is the extent to which employment needs are satisfied(Porter 1963). In this manner, the worker's level of customer orientation is viewed as essential for the company's financial achievement(Hennig-Thurau, Gwinner et al. 2004);(Sergeant and Frenkel 2000).

The gaps of this study are identified from the extant literature. The study conducted by Karatepe and Douri (2012)in Iran included three outcomes of jobs that include job satisfaction, role-prescribed customer service and turnover intentions. They suggest that other outcomes of jobs may also be included in further research including enhanced performance variables such as creativity and those related to the performance of additional roles and responsibilities and career satisfaction. Moreover, they suggest that customer orientation's significance is quite high when considering personality traits especially in service oriented jobs where the employee is the first line of contact with the customer. Implications for future research include discussion of resources for job performance, job engagement on the basis of additional motivational models. The primary purpose of this study is to measure the mediation of $\mathrm{CO}$ between job resourcefulness and employee outcomes including job engagement and career satisfaction in hospitality sector of Pakistan. This sector is an important part of Pakistani service industry. The context of our study is service sector. The service sector accounts for $30 \%$ of global employment. The service sector has provided steady growth to Pakistan's economic growth and services sector share in Gross Domestic Product is over 50\% (Economic survey of Pakistan). The findings of this research may add to the existing literature on customer orientation by addressing how positive employee outcomes are impacted by job resourcefulness.

Bagozzi presented his theory on the reformulation of attitudes in 1992. This theory is the primary basis for hypotheses development and the proposed relationships between the variables. Previous literature and other studies support that this conceptualization is valid in light of empirical proof (Karatepe 2012).Bagozzi (1992)conceptualization is represented in terms of a good appraisal giving arise to an emotional response that determines the behavior of the employee and this is a sequential process. An employee appraises various outcomes that produce specific emotions which in turn, lead to coping responses or behaviors. Following figure presents the schematic of the model under study in this research based on the theory of reformulation of attitude (Bagozzi 1992). Frontline employees in hospitality industry were selected as they are the primary participants in practicing and implementing customer orientation. Interest in customer orientation in the services sector emerged, principally in the 1990s. Interestingly, countless articles provide evidence that being market oriented enhances the quality and financial aspects as well as other benefits of businesses engaged in service ventures. Because of the extraordinary attributes of services, the fulfillment of customer needs is more elemental and crucial for service organizations than other sectors.

\section{Literature Review}

Job Resourcefulness (JR): Job resourcefulness refers to physical, social, or decision-making elements of work which are functional in accomplishing organizational objectives, minimize complaints and the related expenses, and fortify self-improvement and development(Bakker and Demerouti 2007). A workforce that has job resourcefulness has the general capacity to work applying their energies into discovering better approaches for serving clients and meeting their desires. Job resourceful workers are required to overcome issues in the working environment by collecting and utilizing the resources. Research presents evidence that job resourcefulness has positive effect on CO (Licata, Mowen et al. 2003). Earlier studies show that availability of job resources, e.g., rewards, training and development opportunities, management and supervisory support and empowerment lead to increase in the job satisfaction of employees and OC, and decrease the intentions of the employees to consider employment elsewhere. Supervisory support increases the job satisfaction of employees engaged in service oriented jobs especially when they are the first point of contact(Hee Yoon, Hyun Seo et al. 2004); and loyalty(Salanova, Agut et al. 2005). Empowerment relates positively to job satisfaction and affective organizational commitment (Liden, Wayne et al. 2000); (Fulford and Enz 1995). Additionally, where suitable rewards are available the employees' job satisfaction increases as does the affective element of OC(Farrell and Rusbult 1981);(Lewig and Dollard 2003). 
Employee Outcomes-Job Engagement (JE): Job engagement is characterized by vigor, dedication and absorption(González-Romá, Schaufeli et al. 2006). Vigor in working is identifiable by energy and mental dexterity exhibited during work performance. Dedication refers to being highly involved and committed to work while displaying a strong and inherent commitment and affiliation. Employees who exhibit a high level of absorption tend to be completely focused in their work to the extent that they are unaware of any time passing by and generally have issues in disengaging themselves from work (Schaufeli and Bakker 2004). Engaged employees have large amounts of energy and are energetic and display enthusiasm about their work. Employees who display high levels of job engagement perform at higher levels than their peers (Demerouti and Cropanzano 2010), and experience more positive feelings at the workplace such as passion and zeal for work, personal and job satisfaction and tend to appear more content and happy. Positive feelings allow individuals to be more creative and provide the impetus needed for creativity and out of the box thinking to utilize personal resources towards fulfilling work tasks (Carpenter and Fredrickson 2001). Moreover, previous research has demonstrated that engaged workers frequently encounter positive emotions (Schaufeli, Taris et al. 2008), and this is the inspiration behind their productivity.

Career satisfaction (CS): Career satisfaction is satisfaction with one's career all in all. Research on career satisfaction proposes that it is affected by different variables. Career satisfaction is the extent to which employment needs are satisfied and the perception of this need fulfillment by the employee (Porter 1963).It is a "positive (or negative) evaluative judgment one makes about one's profession or vocation circumstance" (Weiss 2002).Career satisfaction is not about a burst of passion or a one-time display of intense emotion. Rather it refers to a consistent feeling of well-being. Career satisfaction of employees grows through psychological and affective commitment to their employments(Locke 1969),(Organ and Near 1985), (Judge and Ilies 2004), (Rich, Lepine et al. 2010).Career satisfaction is a mix of both what a worker feels (influence) about his/her occupation and what he/she considers (discernment) about different parts of his/her profession.

Customer orientation (CO): Customer orientation at the organizational level is important as it adds to the organization's long-term profitability(Macintosh 2007). On the individual level, according to Homburg, Müller et al. (2011) CO is the extent to which service providers connect with customers to satisfy their requirements and build their satisfaction. CO is defined as "inclination to meet customer needs in an on-the-job context" (Brown, Mowen et al. 2002).The concept of customer oriented behavior (COB) refers to practices followed by service providers that lead to fulfilled customers (Frazer Winsted 2000).Past researchers (e.g.(HennigThurau, Gwinner et al. 2004);(Hennig-Thurau and Walsh 2003)) define CO as meeting the requirements of both present and future clients and distinguished different measurements of the CO: technical and social skills, motivation, and the self-perceived power of decision making of the employee. Research has shown that good job outcomes are a result of customer orientation. For example, Donavan, Brown et al. (2004). determined that job satisfaction, organizational citizenship behavior and affective organizational commitment are outcomes of positive customer orientation (Donavan, Brown et al. 2004).Yavas, Karatepe et al. (2011) showed that CO has a negative impact on turnover intentions of workers and leads to job satisfaction and affective organizational commitment.

\section{Hypotheses Building}

Job Resourcefulness and Job Engagement: As already discussed, job resourcefulness refers to physical, social, or authoritative and business segments of work, which are very important in meeting organizational objectives (Bakker and Demerouti 2007).Being inherent motivators, job resources satisfy fundamental individual's needs while fostering their personal growth (Deci and Ryan 1985). These motivators are primarily extrinsic and generally encourage employees to work towards an assignment(Gagné and Deci 2005). In both cases, workers may turn out to be more involved with their specific jobs, as they get satisfaction from it (Schaufeli and Bakker 2004), and ultimately, they perform better(Bakker 2009).Job resources constitute a general class of employment attributes. Interestingly, these attributes are an inherent part of all human capital development processes irrespective of job type or category (Bakker and Demerouti 2007). Past studies have reliably demonstrated that job resources are related positively with job engagement (Halbesleben 2010). Job resources satisfy essential human needs at the workplace, for example, the requirements for self-sufficiency, relatedness and skills(Van den Broeck, Vansteenkiste et al. 2008).Similarly, 
research has demonstrated that job resources especially have an effect on engagement when they have to meet great job demands(Hakanen, Bakker et al. 2005). At the point when workers face big challenges at workplace and have adequate job resources, they can prosper in their job and exceed expectations of their organizations. On the basis of this discussion, this study proposes when employees perceive job resourcefulness they are highly engaged in their job.

H1: JR has a positive relationship with job engagement

Job Resourcefulness and Career Satisfaction: A healthy relationship between the organization and its employees engaged directly in customer interaction is important for employee satisfaction (Hee Yoon, Beatty et al. 2001). Where the personal characteristics of employees' match with demands of work, Edwards, Caplan et al. (1998) suggests, work satisfaction will be higher. The point of view leads to the assumption that where resources are relatively few and employees are highly resourceful, employees are more satisfied with their career and less inclined to leave. Armstrong-Stassen and Ursel (2009)found that organizational resources lead to career satisfaction and retention of older workers. Employees who are highly resourceful can perform work related tasks with a high level of effectiveness even when they have less than sufficient resources to complete them as they are satisfied with their career, thus we hypothesize that.

H2: JR is positively related to career satisfaction.

Job Resourcefulness and Customer Orientation: Employees who display job-resourceful behavior can achieve job related objectives, regardless of the possibility that they are confronted with scarce resources in the working environment. Job resourcefulness is a discriminating personality trait in frontline service jobs, on the grounds that lack of training, insufficient social support, and insufficient empowerment and rewards are common in the service industries. The present study maintains customer orientation is increased due to job resourcefulness. Since employees who are increasingly resourceful employees can perform well under stress and even when they lack resources, hence they ought to be creative in fulfilling customer requirements (Licata, Chakraborty et al. 2008). Research has shown, that job resourcefulness predicts customer orientation (Licata, Chakraborty et al. 2008). Thus, it is hypothesized that

H3: JR is positively related to with CO.

Customer Orientation and Job Engagement: Researchers have suggested that customer orientation impacts the outcomes of various business activities and decision-making because of employees' satisfaction and engagement in work (Zhu, Nakata et al. 2007);(Donavan, Brown et al. 2004);(Anaza and Rutherford 2012);(Zablah, Franke et al. 2012).Babakus and Yavas (2012) concluded that high level customer oriented employees would be aware about future job conditions thereby make themselves more involved and emotionally engaged in the work. AdditionallyDonavan, Brown et al. (2004)reported that employees with strong customer orientation are for the most part likely to be more committed and satisfied such that they do not consider leaving their job. Their performance in handling customers' issues is superior as compare to anything those with low customer orientation. Anaza and Rutherford (2012)and Zablah, Franke et al. (2012)found customer orientation as an antecedent of engagement. On the basis of this discussion, it is hypothesized that

H4: CO has a positive relationship with job engagement.

Customer Orientation and Career Satisfaction: Research proposes that an elevated degree of customer orientation is associated to positive employee outcomes(Judge, Thoresen et al. 2001);(Bettencourt, Gwinner et al. 2001);(Brown and Peterson 1993).Customer orientation is normally characterized as a somewhat stable identity quality or "inclination to address customer issues in work connection" (Brown, Mowen et al. 2002) The outcome of the contact between the workers and the customers amid the administration experiences permits the worker to suspect the client's necessities (Schneider and Bowen 1993).Satisfied workers are more focused and more productive in terms of work output (Heskett, Sasser et al. 1997). Workers tend to be smart in addition to putting in extra effort and these results in higher efficiency (Reichheld, Teal et al. 1996). As indicated by Reichheld, Teal et al. (1996)three criteria drive how hard workers work. They work the hardest when: (1) they have occupation pride, (2) when they discover their occupations interesting and important, and (3) when they perceive advantage from the work they have finished. They express that employees work with confidence when they are sufficiently prepared and have been at work sufficiently long to obtain the advantages from their preparation. In organizations where employees are disconnected from 
their work, there is high level of stress, emotional and professional strain, burnout and a lack of trust on self, teams and the organizations (Caponetti 2012). In the services sector especially, the general understanding is that the environment and climate of an organization trains workers to give superb customer services (Ford, Heaton et al. 2001). There are only a few studies that have linked customer orientation with career satisfaction. For instance, previous research has found correlation between customer orientation and career satisfaction (Hartline and Ferrell 1996);(Pettijohn, Pettijohn et al. 2002);(Stock and Hoyer 2002).Lounsbury, Loveland et al. (2003)examined different personality traits that correlated with career satisfaction in different occupational groups, including some Big Five traits-conscientiousness, extroversion, and openness-and other, narrower traits, such as assertiveness, customer service orientation, and human managerial relations orientation (Lounsbury, Loveland et al. 2003). On the basis of literature, this study suggests that customer orientation leads to career satisfaction.

H5: CO is related positively to career satisfaction

CO as Mediator between JR and Employee Outcomes: Review of existing literature discusses the technicalities of mediation between JR and employee outcomes. Bagozzi's sequential conceptualization of attitude formulation is the basis for the current research. The hypothesized model focuses on CO as it mediates the impact of JR on the employee's engagement with the job and career satisfaction. That is, employees' affective response (customer orientation) that is an outcome of their assessment and understanding of the resources available to them for job performance will improve their resilience in coping with job conditions i.e., engagement and career satisfaction. This leads to the development of the following hypotheses:

H6: The relationship between job resourcefulness and job engagement is partially mediated by CO.

H7: The relationship between job resourcefulness and career satisfaction is partially mediated by customer orientation.

Figure 1: Theoretical Framework

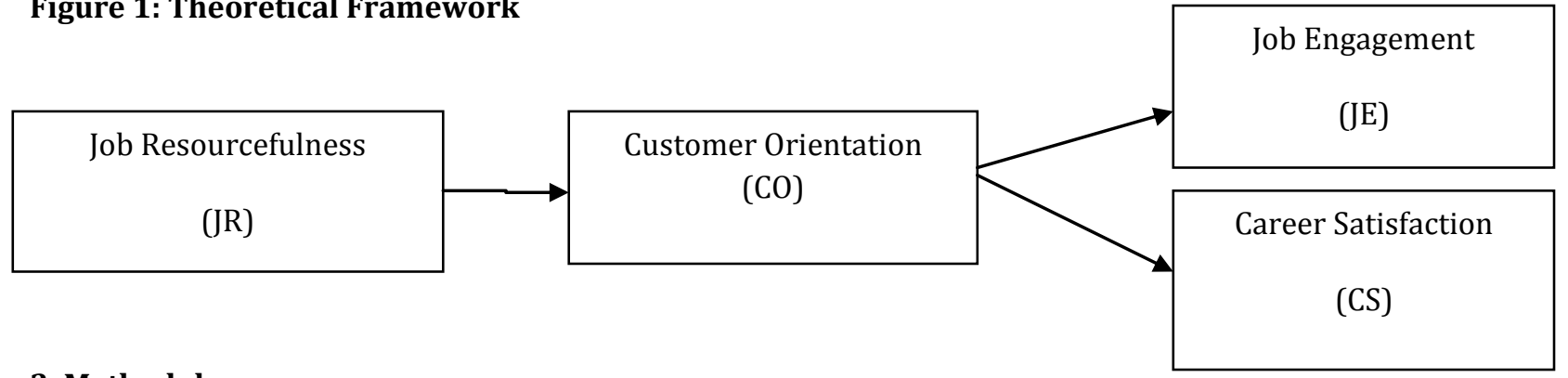

\section{Methodology}

The population for this study compromised of employees working in hospitality industry. Unit of analysis was an individual. Participants were assured that information will be used for research purpose only. We personally delivered set of printed questionnaires. A convenient sample of 300 employees was approached in hospitality industry located within twin cities of Pakistan (Rawalpindi and Islamabad) by contacting their HR managers. However, 257 questionnaires that were completely and properly filled were used only in the study, rest were discarded. A five point Likert type scale was used where $1=$ strongly disagree, and $5=$ strongly agree.

Measures: Four items were used to measure job resourcefulness (Harris, Artis et al. 2006). Four items were used to operationalize customer orientation (Licata, Mowen et al. 2003). Five items from career satisfaction scale (Greenhaus, Parasuraman et al. 1990). Finally nine items scale of job engagement developed was also used (Schaufeli, Bakker et al. 2006). The questionnaire consists of 2 parts with section A and B. Section A consist of items seeking demographics gender, experience level. Section B consists of the items. Analysis was conducted using two steps, in first step confirmatory factor analysis was performed in which model fitness and factor loadings were considered. In the second step structural model is tested. 


\section{Results}

Table 1: Descriptive statistics

\begin{tabular}{llll}
\hline Demographic characteristics & Frequency & Percentage \\
\hline Gender & Male & 175 & 68.1 \\
Age & Female & 82 & 31.9 \\
& $18-24$ & 65 & 25.3 \\
& $25-34$ & 117 & 45.5 \\
Experience & $35-44$ & 63 & 24.5 \\
& $45-54$ & 12 & 4.7 \\
& Less than 5 years & 110 & 42.8 \\
Education & $5-10$ years & 109 & 42.4 \\
& $11-15$ Years & 24 & 9.3 \\
& More than 15 years & 14 & 5.4 \\
& Bachelor's degree or 100 & 39 \\
& below & & \\
& Master's degree & or 157 & 61 \\
\hline
\end{tabular}

Demographic Analysis: Table 1 shows that the percentage of male respondents is 68.1 and the percentage of female respondents is 31.9. The table further shows that majority of employees fall in age bracket of 25-34 years. Majority of employees had less than 10 years of experience. Finally the table shows that majority of the respondents have Masters or higher degree holder.

CFA - Factor Loadings: In the first step CFA was performed. Model fitness was good. CMIN/Df= 2.053, $\mathrm{CFI}=0.901, \mathrm{IFI}=0.903, \mathrm{RMSEA}=0.064$. Table 2 shows that all the factor loadings are significant and greater than 0.50 , therefore all of these items were used in the analysis (except, one item from career satisfaction was deleted due to its low loading). There is convergent validity between the items(Anderson and Gerbing 1988) Moreover, using different $\mathrm{X}^{2}$ difference tests $(\mathrm{p}<0.01)$ employing measures of each pair of variables, discriminant validity was also calculated. For each pair of constructs, a two-factor CFA model was examined. Then, a single factor solution was enforced through forcing the various items measuring the variables. By doing so, the model fit significantly declined. These results are sufficient to prove discriminant validity (Anderson and Gerbing 1988).

Table 2: Factor Loadings

\begin{tabular}{lllllll}
\hline $\begin{array}{l}\text { Latent } \\
\text { Variables }\end{array}$ & & $\begin{array}{l}\text { Observed } \\
\text { Variables }\end{array}$ & $\begin{array}{l}\text { Standardized } \\
\text { Estimate }\end{array}$ & S.E. & C.R. & P \\
\hline JE & $\rightarrow$ & ABSORPTION & .945 & .173 & 6.985 & $* * *$ \\
JE & $\rightarrow$ & DEDICATION & .879 & .170 & 7.179 & $* * *$ \\
JE & $\rightarrow$ & VIGOR & .664 & & & \\
ABSORPTION & $\rightarrow$ & JE6 & .546 & .122 & 7.279 & $* * *$ \\
ABSORPTION & $\rightarrow$ & JE5 & .566 & .119 & 7.482 & $* * *$ \\
ABSORPTION & $\rightarrow$ & JE4 & .596 & & & \\
VIGOR & $\rightarrow$ & JE3 & .546 & .104 & 7.191 & $* * *$ \\
VIGOR & $\rightarrow$ & JE2 & .656 & .092 & 8.173 & $* * *$ \\
VIGOR & $\rightarrow$ & JE1 & .783 & & & \\
DEDICATION & $\rightarrow$ & JE9 & .622 & .099 & 8.313 & $* * *$ \\
DEDICATION & $\rightarrow$ & JE8 & .528 & .096 & 7.203 & $* * *$ \\
DEDICATION & $\rightarrow$ & JE7 & .721 & & & \\
CO & $\rightarrow$ & CO4 & .577 & .167 & 7.934 & $* * *$ \\
CO & $\rightarrow$ & CO3 & .691 & .161 & 7.810 & $* * *$ \\
CO & $\rightarrow$ & CO2 & .673 & &
\end{tabular}




\begin{tabular}{lllllll}
\hline $\begin{array}{l}\text { Latent } \\
\text { Variables }\end{array}$ & & $\begin{array}{l}\text { Observed } \\
\text { Variables }\end{array}$ & $\begin{array}{l}\text { Standardized } \\
\text { Estimate }\end{array}$ & S.E. & C.R. & P \\
\hline CO & $\rightarrow$ & CO1 & .705 & .190 & 8.026 & $* * *$ \\
JRF & $\rightarrow$ & JRF4 & .685 & & & \\
JRF & $\rightarrow$ & JRF3 & .670 & .106 & 8.821 & $* * *$ \\
JRF & $\rightarrow$ & JRF2 & .756 & .111 & 9.565 & $* * *$ \\
JRF & $\rightarrow$ & JRF1 & .677 & .101 & 8.893 & $* * *$ \\
CS & $\rightarrow$ & CS5 & .616 & & & \\
CS & $\rightarrow$ & CS3 & .709 & .132 & 8.544 & $* * *$ \\
CS & $\rightarrow$ & CS2 & .763 & .147 & 8.905 & $* * *$ \\
CS & $\rightarrow$ & CS1 & .701 & .136 & 8.489 & $* * *$ \\
\hline
\end{tabular}

Table 3 provides the values for descriptive statists of study variables. The co-efficient of Cronbach's alpha is on the diagonal in bold letters, in this research the reliability value of all the variables is greater than 0.70 (Nunnally 1978) which is satisfactory. This table also shows the relationship between variables. The result shows there is a positive and significant relationship among all the variables.

Table 3: Descriptive, Correlation and Reliability Analysis

\begin{tabular}{lrccrcccc} 
Constructs & Minimum & Maximum & Mean & $\begin{array}{c}\text { Std. } \\
\text { Deviation }\end{array}$ & I & II & III & IV \\
JR & 1 & 5 & 3.6500 & .84686 & $(\mathbf{0 . 7 9 0})$ & & & \\
CO & 1 & 5 & 3.4695 & .87236 & $.316^{* *}$ & $\mathbf{( 0 . 7 5 5 )}$ & & \\
JE & 1 & 5 & 3.6515 & .69301 & $.419^{* *}$ & $.652^{* *}$ & $\mathbf{( 0 . 7 9 8 )}$ & \\
J CS & 1 & 5 & 3.5306 & .81407 & $.349^{* *}$ & $.432^{* *}$ & $.485^{* *}$ & $\mathbf{( 0 . 7 6 3 )}$ \\
\hline
\end{tabular}

**. Correlation is significant at the 0.01 level (2-tailed).

$\mathrm{JR}=\mathrm{Job}$ resourcefulness, $\mathrm{CO}=$ Customer orientation JE $=\mathrm{Job}$ engagement, $\mathrm{CS}=$ Career satisfaction

Hypotheses testing: In the second step of analysis, structural model was tested. Overall, model fitness of the structural model was good. CMIN/Df= 2.079, $\mathrm{CFI}=0.897, \mathrm{IFI}=0.890, \mathrm{RMSEA}=0.065$. Further, the significance and magnitudes of hypothesized relationships were examined. The following table is tested using structural equation modeling technique through AMOS 21 software. The results reveal a positive and significant impact of job resourcefulness on all the three outcomes i.e., job engagement $(\beta=0.237, p$ value $<0.001)$, career satisfaction $(\beta=0.256$, $p$ value $<0.001)$, customer orientation $(\beta=0.409$, p value $<0.001)$. These results show that job resourcefulness has the highest impact on customer orientation out of three outcomes followed by career satisfaction and job engagement. The results further show that customer orientation has a positive and significant impact on job engagement $(\beta=0.661$, p value $<0.001)$ and career satisfaction $(\beta=0.476$, p value $<$ $0.001)$. These results show that customer orientation is strongly related to job engagement. The same is represented by the structural diagram below. Thus, these hypotheses are accepted.

Table 4: Hypotheses Testing: Main Model

\begin{tabular}{|c|c|c|c|c|c|c|c|c|}
\hline \multicolumn{3}{|c|}{ Relationships } & Hypotheses & Standardized & S.E. & C.R. & $\mathbf{P}$ & Label \\
\hline JRF & $-\rightarrow$ & JE & H1 & 0.237 & .057 & 3.199 & $* * *$ & Accepted \\
\hline JRF & $\rightarrow$ & CS & $\mathrm{H} 2$ & 0.256 & .068 & 3.072 & $* * *$ & Accepted \\
\hline JRF & $\rightarrow$ & $\mathrm{CO}$ & H3 & 0.409 & .070 & 4.529 & $* * *$ & Accepted \\
\hline $\mathrm{CO}$ & $\rightarrow$ & JE & $\mathrm{H} 4$ & 0.661 & .128 & 6.037 & *** & Accepted \\
\hline $\mathrm{CO}$ & $\rightarrow$ & CS & H5 & 0.476 & 103 & 4.858 & $* * *$ & Accepted \\
\hline
\end{tabular}


Figure 2: Structural model testing

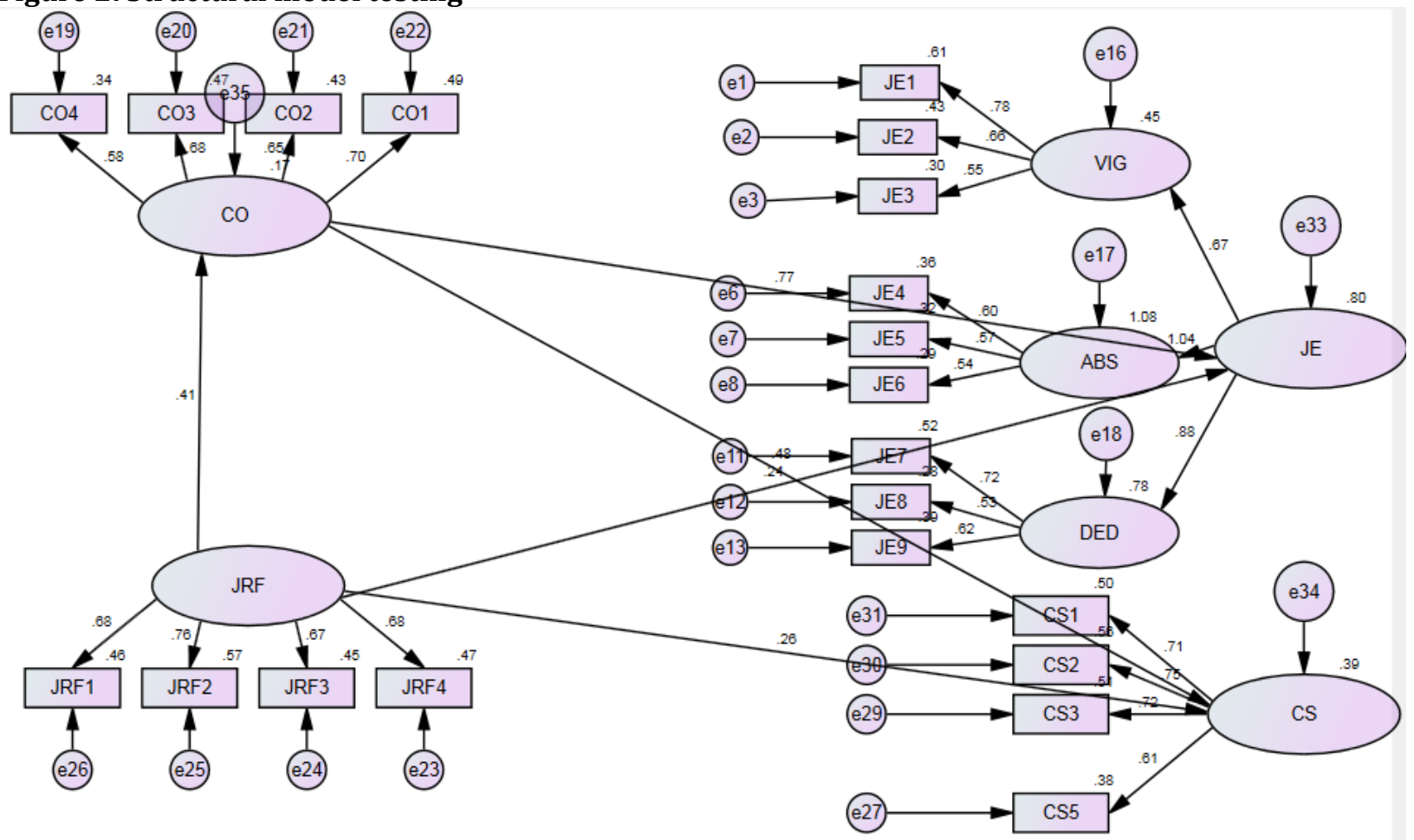

Mediation analysis: This study used two methods to examine the mediating effect of customer orientation on job resourcefulness, job engagement and career satisfaction through (i) Baron and Kenny (1986) and (ii)Preacher and Hayes (2004). Using Baron and Kenny (1986) approach, first a direct model was tested, which comes up with positive effect of job resourcefulness on both job engagement $(\beta=0.581$, p value < $0.001)$ and career satisfaction $(\beta=0.495$, $p$ value $<0.001)$. In the next step a second model was tested using customer orientation as a mediator. The results reveal that there were reduction in both beta weights of the effects and both the effects were still significant (job engagement $\beta=0.237, p$ value $<0.001$; career satisfaction $\beta=0.256$, p value $<0.001$ ), that is an evidence of a partial mediation. Thus, hypotheses H6 and H7 are also supported. To further assess the significance of the mediation, bootstrapping methods were applied. The benefit of testing the indirect effect through the bootstrapping method is that it does not assume that the standard error distribution relates to the indirect outcomes and provides confidence intervals for the estimate. In comparison to the Sobel test, this technique is considered better. The Sobel test assumes that the standard errors have a normal distribution. Using bootstrapping, if the zero falls within the $95 \%$ confidence interval, it is established that the indirect effect is significant. The results presented in the last two columns of Table 7.5 were based on 2000 bootstrapped samples. The 95\% confidence intervals were accelerated and corrected for bias (Preacher and Hayes 2004). Significantly different indirect effects were apparent in the results from zero at $\mathrm{p}<.05$ (two tailed). It can be concluded that the $\mathrm{CO}$ partially mediated the relationship between JR and job engagement and career satisfaction respectively (job engagement $\beta=0.244, p$ value $<$ 0.001 ; career satisfaction $\beta=0.159$, p value $<0.001$ ). Thus, it could be inferred that the job resourcefulness has both direct and indirect effects on positive employee outcomes.

Discussion: The aim of our study was to find impact of job resourcefulness and communication style on employee outcomes (job engagement, and career satisfaction). The study further aimed to examine how customer orientation mediates the interaction between JR and employee outcomes. First and second hypotheses anticipated the positive impact of job resourcefulness on employee outcomes. The hypotheses were substantiated as job resourcefulness has significant positive impact on employee outcomes including job engagement (H1) and career satisfaction (H2) respectively. The review of the literature extensively supports the premise that in environments where employees are more resourceful, job engagement would increase. This was also conclusively established through the results that resourceful employees are highly engaged in their work (Halbesleben 2010);(Hakanen, Bakker et al. 2005). Similarly the second hypothesis is 
also substantiated that job resourcefulness is perceived as organizational support lead to career satisfaction (Armstrong-Stassen and Ursel 2009).

Table 5: Hypotheses testing: Mediation Analysis Model

\begin{tabular}{lllllll}
\hline Relationship & $\begin{array}{l}\text { Direct } \\
\text { relation } \\
\text { without } \\
\text { mediator }\end{array}$ & $\begin{array}{l}\text { Direct } \\
\text { relation } \\
\text { with } \\
\text { mediator }\end{array}$ & $\begin{array}{l}\text { Indirect } \\
\text { relation } \\
\text { through } \\
\text { bootstrapping }\end{array}$ & $\begin{array}{l}\text { Lower } \\
\text { confidence } \\
\text { interval } \\
\text { (at 95\%) }\end{array}$ & $\begin{array}{l}\text { Upper } \\
\text { confidence } \\
\text { interval } \\
\text { (at 95\%) }\end{array}$ & Results \\
\hline JR-CO-JE & $0.581^{* * *}$ & $0.237^{* * *}$ & $0.244^{* * *}$ & 0.110 & 0.490 & Partial mediation \\
JR-CO-CS & $0.495^{* * *}$ & $0.256^{* * *}$ & $0.159^{* * *}$ & 0.062 & 0.340 & Partial mediation \\
\hline
\end{tabular}

Third hypothesis anticipated that job resourcefulness of service employees has a positive relationship with customer orientation. A resourceful employee is assumed to have better customer orientation due to being more creative and having more initiative (Licata, Chakraborty et al. 2008). The hypothesis was substantiated that JR is significantly related to customer orientation. Fourth and fifth hypotheses anticipated that customer orientation has positive relationship with employee outcomes including job engagement (H4) and career satisfaction (H5). Customer oriented employees tend to make more effort in ensuring that the customer needs are known and met effectively. This provides drive and motivation and increases overall employee engagement and improved career choices. The results of this study substantiate the hypothesis that customer orientation has significant relationship with career satisfaction (Lounsbury, Loveland et al. 2003) and job engagement (Anaza and Rutherford 2012);(Zablah, Franke et al. 2012).Sixth hypothesis anticipated that CO has a partial mediating impact on JR and job engagement. Since other variables that possibly affect the relationship between JR and job engagement, and other aspects of relationship marketing were not considered, partial mediation and limited significance of the indirect relationship was established. The hypothesis was substantiated that customer orientation partially mediates the relation between job resourcefulness and job engagement.

Seventh hypothesis anticipated that CO partially mediates the relationship between JR and career satisfaction. The indirect relationship between JR and employee outcome through customer orientation was significant as compared to the relationship without customer orientation. Therefore, the results of the study supported the hypothesis by showing partial mediation. The overall results prove the basis of the model, postulating that job resourcefulness and positive customer orientation lead to improved employee outcomes. Where organizations provide the support necessary and emphasize customer orientation behavior, employees are willing to show good performance even in the absence of resources. Employees are involved and engaged with their work, they are creative and have higher career satisfaction and increased organizational affinity which leads to improved organizational performance. Involved employees are generally more customer oriented, and utilize resourcefulness to better cater to customers which also leads to improved employee outcomes.

\section{Limitations/Future recommendations}

The findings are limited to some extent by sample size because of shortage of resources and time constraints. The research may also be done by considering other mediators such as customer satisfaction skills and involving customers to solve problems which are neglected in present study. Future studies may be conducted in other sectors to understand the dynamics of this relationship in more depth and identify other factors contributing towards employee outcomes. Future studies should also examine other outcomes not only on employee level but also customer related outcomes e.g., customer purchase intention, customer buying behavior and customer satisfaction and organizational level including organizational performance and organizational innovation. This study took data on one level only; in future data can be taken from different levels of management.

Implications: In every organization, policies should be adopted to support development and implementation of customer orientation philosophy and practices. Emphasis should be on providing employees with all requisites resources before assigning them any task or duty and while developing expectations from them. 
This leads to employees being engaged and involved in work, with work and career satisfaction leading to improved organizational productivity and effectiveness. Organizations must expend due effort towards the development of an environment and climate where employees have higher career satisfaction and therefore are content which leads to an improved sense of engagement, well-being and affiliation. This promotes teamwork and knowledge sharing and will enhance overall job engagement and productivity. The research study suggests that Job resourcefulness and customer orientation are necessary to enhance employee engagement and career satisfaction for organizational development and productivity.

\section{References}

Anaza, N. A. and B. Rutherford (2012). How organizational and employee-customer identification, and customer orientation affect job engagement. Journal of Service Management $t_{2}$ 23(5): 616-639.

Anderson, J. C. and D. W. Gerbing (1988). Structural equation modeling in practice: A review and recommended two-step approach. Psychological bulletin, 103(3): 411.

Armstrong-Stassen, M. and N. D. Ursel (2009). Perceived organizational support, career satisfaction, and the retention of older workers. Journal of occupational and organizational psychology, 82(1): 201-220.

Babakus, E. and U. Yavas (2012). Customer orientation as a buffer against job burnout. The Service Industries Journal, 32(1): 5-16.

Babakus, E., U. Yavas, et al. (2009). The role of customer orientation as a moderator of the job demandburnout-performance relationship: A surface-level trait perspective. Journal of Retailing, 85(4): 480492.

Bagozzi, R. P. (1992). The self-regulation of attitudes, intentions, and behavior. Social psychology quarterly: 178-204.

Bakker, A. B. (2009). Building engagement in the workplace. The peak performing organization: 50-72.

Bakker, A. B. \& E. Demerouti (2007). The job demands-resources model: State of the art. Journal of managerial psychology, 22(3): 309-328.

Baron, R. M. \& D. A. Kenny (1986). The moderator-mediator variable distinction in social psychological research: Conceptual, strategic, and statistical considerations. Journal of personality and social psychology, 51(6): 1173.

Bettencourt, L. A., K. P. Gwinner, et al. (2001). A comparison of attitude, personality, and knowledge predictors of service-oriented organizational citizenship behaviors. Journal of applied psychology, 86(1): 29.

Boles, J. S., B. J. Babin, et al. (2001). An examination of the relationships between retail work environments, salesperson selling orientation-customer orientation and job performance. Journal of Marketing Theory and Practice, 9(3): 1-13.

Brown, S. P. and R. A. Peterson (1993). Antecedents and consequences of salesperson job satisfaction: Metaanalysis and assessment of causal effects. Journal of marketing research, 30(1): 63.

Brown, T. J., J. C. Mowen, et al. (2002). The customer orientation of service workers: Personality trait effects on self-and supervisor performance ratings. Journal of Marketing Research, 39(1): 110-119.

Caponetti, A. R. (2012). The correlates of work role stress with employee burnout, engagement.

Carpenter, M. A. and J. W. Fredrickson (2001). Top management teams, global strategic posture, and the moderating role of uncertainty. Academy of Management journal, 44(3): 533-545.

Deci, E. L. and R. M. Ryan (1985). The general causality orientations scale: Self-determination in personality. Journal of research in personality, 19(2): 109-134.

Demerouti, E. and R. Cropanzano (2010). From thought to action: Employee work engagement and job performance. Work engagement: A handbook of essential theory and research, 65: 147-163.

Donavan, D. T., T. J. Brown, et al. (2004). Internal benefits of service-worker customer orientation: Job satisfaction, commitment, and organizational citizenship behaviors. Journal of marketing, 68(1): 128146.

Edwards, J. R., R. D. Caplan, et al. (1998). Person-environment fit theory. Theories of organizational stress, 28 : 67.

Farrell, D. and C. E. Rusbult (1981). Exchange variables as predictors of job satisfaction, job commitment, and turnover: The impact of rewards, costs, alternatives, and investments. Organizational behavior and human performance, 28(1): 78-95. 
Ford, R. C., C. P. Heaton, et al. (2001). Delivering excellent service: lessons from the best firms. California Management Review, 44(1): 39-56.

Frazer Winsted, K. (2000). Service behaviors that lead to satisfied customers. European Journal of Marketing 34(3/4): 399-417.

Fulford, M. D. and C. A. Enz (1995). The impact of empowerment on service employees. Journal of Managerial Issues, 161-175.

Gagné, M. and E. L. Deci (2005). Self-determination theory and work motivation. Journal of Organizational behavior 26(4): 331-362.

González-Romá, V., W. B. Schaufeli, et al. (2006). Burnout and work engagement: Independent factors or opposite poles? Journal of vocational behavior, 68(1): 165-174.

Greenhaus, J. H., S. Parasuraman, et al. (1990). Effects of race on organizational experiences, job performance evaluations, and career outcomes. Academy of management Journal, 33(1): 64-86.

Hakanen, J. J., A. B. Bakker, et al. (2005). How dentists cope with their job demands and stay engaged: The moderating role of job resources. European journal of oral sciences, 113(6): 479-487.

Halbesleben, J. R. (2010). A meta-analysis of work engagement: Relationships with burnout, demands, resources, and consequences. Work engagement: A handbook of essential theory and research, 8: 102117.

Harris, E. G., A. B. Artis, et al. (2006). Role stressors, service worker job resourcefulness, and job outcomes: An empirical analysis. Journal of Business Research, 59(4): 407-415.

Hartline, M. D. and O. C. Ferrell (1996). The management of customer-contact service employees: an empirical investigation. The Journal of Marketing, 52-70.

Hee Yoon, M., S. E. Beatty, et al. (2001). The effect of work climate on critical employee and customer outcomes: An employee-level analysis. International Journal of Service Industry Management, 12(5): 500-521.

Hee Yoon, M., J. Hyun Seo, et al. (2004). Effects of contact employee supports on critical employee responses and customer service evaluation. Journal of Services Marketing, 18(5): 395-412.

Hennig-Thurau, T., K. P. Gwinner, et al. (2004). Electronic word-of-mouth via consumer-opinion platforms: what motivates consumers to articulate themselves on the internet? Journal of interactive marketing 18(1): 38-52.

Hennig-Thurau, T. and G. Walsh (2003). Electronic word-of-mouth: Motives for and consequences of reading customer articulations on the Internet. International journal of electronic commerce, 8(2): 51-74.

Heskett, J., W. E. Sasser, et al. (1997). The Service Profit Chain: How Leading Companies Link Profit and Growth to Loyalty, Satisfaction, and Value (Цепочка создания прибыли в сфере услуг: как ведущие компании связывают прибыль и рост с лояльностью, удовлетворением и ценностью).

Homburg, C., M. Müller, et al. (2011). When should the customer really be king? On the optimum level of salesperson customer orientation in sales encounters. Journal of Marketing, 75(2): 55-74.

Huang, J.-H. and C.-C. Chang (2008). The role of personality traits in online consumer complaint behavior and service recovery expectation. Social Behavior and Personality: an international journal, 36(9): 1223-1232.

Hurley, R. F. and G. T. M. Hult (1998). Innovation, market orientation, and organizational learning: an integration and empirical examination. The Journal of marketing, 42-54.

Judge, T. A. and R. Ilies (2004). Affect and job satisfaction: a study of their relationship at work and at home. Journal of Applied Psychology, 89(4): 661.

Judge, T. A., C. J. Thoresen, et al. (2001). The job satisfaction-job performance relationship: A qualitative and quantitative review, American Psychological Association.

Karatepe, O. M. (2012). Perceived organizational support, career satisfaction, and performance outcomes: a study of hotel employees in Cameroon. International Journal of Contemporary Hospitality Management, 24(5): 735-752.

Karatepe, O. M. and B. G. Douri (2012). Does customer orientation mediate the effect of job resourcefulness on hotel employee outcomes? Evidence from Iran. Journal of Hospitality and Tourism Management, 19(1): 133-142.

Lewig, K. A. and M. F. Dollard (2003). Emotional dissonance, emotional exhaustion and job satisfaction in call centre workers. European Journal of Work and Organizational Psychology, 12(4): 366-392.

Licata, J. W., G. Chakraborty, et al. (2008). The consumer's expectation formation process over time. Journal of Services Marketing, 22(3): 176-187. 
Licata, J. W., J. C. Mowen, et al. (2003). On the trait antecedents and outcomes of service worker job resourcefulness: A hierarchical model approach. Journal of the Academy of Marketing science, 31(3): 256-271.

Liden, R. C., S. J. Wayne, et al. (2000). An examination of the mediating role of psychological empowerment on the relations between the job, interpersonal relationships, and work outcomes. Journal of applied psychology, 85(3): 407.

Locke, E. A. (1969). What is job satisfaction? Organizational behavior and human performance 4(4): 309-336.

Lounsbury, J. W., J. M. Loveland, et al. (2003). An investigation of personality traits in relation to career satisfaction. Journal of Career Assessment, 11(3): 287-307.

Macintosh, G. (2007). Customer orientation, relationship quality, and relational benefits to the firm. Journal of Services Marketing, 21(3): 150-159.

Nunnally, J. (1978). Psychometric methods, New York: McGraw-Hill.

Organ, D. W. and J. P. Near (1985). Cognition vs affect in measures of job satisfaction. International Journal of Psychology, 20(2): 241-253.

Pettijohn, C. E., L. S. Pettijohn, et al. (2002). The influence of salesperson skill, motivation, and training on the practice of customer-oriented selling. Psychology \& Marketing, 19(9): 743-757.

Porter, L. W. (1963). Job attitudes in management: IV. Perceived deficiencies in need fulfillment as a function of size of company. Journal of applied Psychology, 47(6): 386.

Preacher, K. J. and A. F. Hayes (2004). SPSS and SAS procedures for estimating indirect effects in simple mediation models. Behavior research methods, 36(4): 717-731.

Reichheld, F. F., T. Teal, et al. (1996). The loyalty effect, Harvard business school press Boston, MA.

Rich, B. L., J. A. Lepine, et al. (2010). Job engagement: Antecedents and effects on job performance. Academy of management journal, 53(3): 617-635.

Salanova, M., S. Agut, et al. (2005). Linking organizational resources and work engagement to employee performance and customer loyalty: the mediation of service climate. Journal of applied Psychology, 90(6): 1217.

Saxe, R. and B. A. Weitz (1982). The SOCO scale: A measure of the customer orientation of salespeople. Journal of marketing research, 343-351.

Schaufeli, W. B. and A. B. Bakker (2004). Job demands, job resources, and their relationship with burnout and engagement: A multi-sample study. Journal of organizational Behavior, 25(3): 293-315.

Schaufeli, W. B., A. B. Bakker, et al. (2006). The measurement of work engagement with a short questionnaire: A cross-national study. Educational and psychological measurement, 66(4): 701-716.

Schaufeli, W. B., M. Salanova, et al. (2002). The measurement of engagement and burnout: A two sample confirmatory factor analytic approach. Journal of Happiness studies, 3(1): 71-92.

Schaufeli, W. B., T. W. Taris, et al. (2008). Workaholism, burnout, and work engagement: three of a kind or three different kinds of employee well-being? Applied Psychology, 57(2): 173-203.

Schneider, B. and D. E. Bowen (1993). The service organization: Human resources management is crucial. Organizational Dynamics, 21(4): 39-52.

Sergeant, A. and S. Frenkel (2000). When do customer contact employees satisfy customers? Journal of Service Research, 3(1): 18-34.

Stock, R. M. and W. D. Hoyer (2002). Leadership style as driver of salespeoples' customer orientation. Journal of market-focused management, 5(4): 355-376.

Van den Broeck, A., M. Vansteenkiste, et al. (2008). Explaining the relationships between job characteristics, burnout, and engagement: The role of basic psychological need satisfaction. Work \& Stress, 22(3): 277-294.

Weiss, H. M. (2002). Deconstructing job satisfaction: Separating evaluations, beliefs and affective experiences. Human resource management review, 12(2): 173-194.

Yavas, U., O. M. Karatepe, et al. (2011). Do customer orientation and job resourcefulness moderate the impact of interrole conflicts on frontline employees' performance? Tourism and Hospitality Research, 11(2): 148-159.

Zablah, A. R., G. R. Franke, et al. (2012). How and when does customer orientation influence frontline employee job outcomes? A meta-analytic evaluation. Journal of marketing, 76(3): 21-40.

Zhu, Z., C. Nakata, et al. (2007). Self-service technology effectiveness: the role of design features and individual traits. Journal of the Academy of Marketing Science, 35(4): 492-506. 